

\title{
Synthesis of an Antimicrobial Thio-anthraquinone Compound to Produce Biodegradable Electrospun Mats for Tissue Engineering Purposes
}

\author{
Yesim Muge Sahin* \\ ${ }^{1}$ Istanbul Arel University, ArelPOTKAM (Polymer Technologies and Composite Application and \\ Research Center), 34537, Istanbul, Turkey \\ ${ }^{2}$ Istanbul Arel University, Faculty of Engineering and Architecture, Department of Biomedical \\ Engineering, 34537, Istanbul, Turkey
}

Abstract: In this work, a novel S-substituted bioactive anthraquinone compound is synthesized with a new, easy and less energetic reaction methodfrom 1-chloro-9,10-dihydrodiagnosisxy-anthraquinone and butyl-3-mercaptopropionate (Compound 3) for the first time in the literature. The synthesized structure is purified by column chromatography and then characterized with various spectroscopic methods (NMR, MS, FT-IR, UV). The investigation of the antimicrobial properties of the purified structure reveals remarkable biological properties. Compound 3 is not only effective against yeasts and fungi but also displays significant inhibitory effects on the growth of the tested Gram positive bacteria similiar to that of a positive control (Gentamicin). Subsequently, biodegradable electrospun mats are produced via electrospinning method for their usage as a biomaterial. Structural (FTIR), morphological (FEG-SEM) biological (antimicrobial and in-vitro tests) and mechanical (tensile testing) characterizations are conducted for these nanobiomaterials. Presenting an advantage of the novel antimicrobial compound, all produced electrospun nanobiocomposites exhibit remarkable cell viability\% and mechanical properties as the amount of Compound 3 increases. Cell viability values are $95 \%$ or greater for all polymeric nanocomposites whereas, the best cell viability\% and mechanical proprties are obtained for PCL-8\% Compound3 composite. The obtained electrospun mats are good candiates for biomaterials for tissue engineering purposes and wound healing materials with a purposeful compound synthesis and a subsequent nanobiocomposite production.

Keywords: Anthraquinone, synthesis, biodegradable material, electrospun mat, biomaterial.

Submitted: May 09, 2018. Accepted: September 18, 2018.

Cite this: Şahin Y. Synthesis of an Antimicrobial Thio-anthraquinone Compound to Produce Biodegradable Electrospun Mats for Tissue Engineering Purposes. JOTCSA. 2018;5(3):1119-34.

DOI: http://dx.doi.org/10.18596/jotcsa.422255.

Corresponding author. E-mail: ymugesahin@arel.edu.tr.

\section{INTRODUCTION}

Natural products have great potential for medical applications. Recently, anthraquinone derivatives have gained special interest owing to their large potential applications as antifungal, antiviral, antibacterial agents for biological activities (2-6). Aloe-emodin, an anthraquinone derivative, is a potential antileukemic material (7). This molecule chemically stumilates the growth and proliferation of normal mouse splenocytes and shows dose-dependent cytoxicity against cancer cell lines. On the other hand, being effective to various cancer type and multiple sclerosis, Mitoxantrone, an anthraquinone analogue, is known as a synthetic anticancer analog of anthracycline antibiotics (8-12). Several studies have been conducted to understand the mechanism of mitoxantrone and it is revealed that the nuclear DNA is the primary target and the planar anthraquinone ring inserts between DNA base pairs. Consequently, negatively charged phosphate groups of DNA are found to bind to the nitrogen-containing side chains (1315). Being an anticancer drug, Mitoxantrone is 
a valuable inhibitor for the enzymes that are responsible for repairing a damaged DNA $(16,17)$. Several anthraquinone analogues have been evaluated as potential materials in various applications.

Recently, many studies have been conducted with both isolated $[18,19]$ and synthesized anthraquinone derivatives $[20,21]$ since they present potential therapeutic uses such as antibacterial, antifungal agents, and in other biological activities. Furthermore, various functional groups have been substituted to anthraquinone molecules to improve biocompatibility, antimicrobial and anticancer properties for tissue engineering purposes. Among these molecules amino, hydroxy, metoxy, cyano, thiazoline, and thiophene etc. derivatives [22-25] have been synthesized. Although, for naphthaquinones, a family of quinones, thiol derivatives have been evaluated detailly for their antibacterial and antifungal activity [26], very few studies have been conducted with thio-substituted anthraquinones to identify their biological properties [27]. Moreover, in the literature some isolated natural thioantraquinone derivatives were extensively used for their antimicrobial and anticancer properties [28]. These investigations have been the motivation of this work to focus on the synthesis of anthraquinone molecules and their subsequent nanocomposite production for tissue engineering materials.

Synthesis of some anthraquinone derivatives in the literature have been conducted with expensive and hardly obtained chemicals like cesium carbonate. Also organic solvents, which are hazardous and hardly purified, are used for such synthesis under nitrogen conditions $(29,30)$. Thus sustainable production of an anthraquinone has become difficult. In our previous study, a novel practical, economical and one-step synthesis methodology has been established to simple synthesis of anthraquinone derivatives (1). Ethylene glycol is used as an organic solvent in the present study. Since reactions are conducted under heat, the usage of nonvolatile, readily available and inexpensive solvent such as ethylene glycol presents the novelty of our synthesis method. On the other hand, being biocompatible, biodegradable and presenting higher mechanical properties in comparison to its natural polymer analogues, Polycaprolactone $(P C L)$ is preferred especially in tissue engineering applications. Moreover, the degradation products (succinic acid, butyric acid, valeric acid and caproic acid) of PCL don't present a toxic effect and inflammatory reactions. These effects make PCL preferable in the regeneration of bone, epidermis, nerve and retina in tissue engineering $(31,32)$. The synthetic polymer PCL, among the few FDA (Food and Drug Administration) approved polymers and present antimicrobial effect can be utilized as biomaterials for such purposes (33).

Electrospinning is an efficient technique that is used for the fabrication of polymer nanofibers. In recent years, various polymeric and composite solutions have been successfully converted into electrospun mats of ultrafine fibers $(34,35)$. Presenting higher volume/surface area, these nanofiber mats result in superior properties especially in biological (antimicrobial and cell adhesion) and mechanical aspects $(31,36,37)$. As a consequence of these, obtained electrospun mats can have potential applications as regenerative or wound healing biomaterials in tissue engineering $(38,39)$.

In the present paper, a comprehensive study has been conducted starting from the synthesis of a noval, biologically active compound, and its production of to electrospun biocomposites. The obtained biomaterials can find applications as wound healing material or a biomaterial for regenerative tissue engineering purposes.

\section{MATERIALS AND METHODS}

\section{Materials and Characterization}

All chemicals are obtained from Sigma Aldrich and used as received. The obtained products are purified by column chromatography on Silica gel (Fluka Silicagel 60, particle size 63-200 $\mu \mathrm{m}$ ). TLC plates coated with silica 60F254 (Merck, Darmstadt) are used under ultraviolet light (254 $\mathrm{nm}$ ). To identify the melting points of the products, a Buchi B-540 melting point apparatus is used. Structure investigations for both Compound 3 and the nanocomposites are identified by Fourier transform infrared (FTIR) spectroscopy. The IR spectra were recorded on a JASCO (model 6600) FTIR spectroscopy in the region $400-4000 \mathrm{~cm}^{-1}$ at a resolution of $1 \mathrm{~cm}^{-1}$ and 8 scans are performed for each detection. ATR technique is used. UV spectrum is gauged by using Shimadzu UV-VIS Spectrophotometer 2600. ${ }^{1} \mathrm{H}$ and ${ }^{13} \mathrm{C}$ NMR spectra are conducted by Varian UNITY INOVA which are operated at 500 $\mathrm{MHz}$. Mass analysis is done on a Thermo Advantage MAX LC/MS/MS spectrometer.

\section{Synthesis and structural characterization of thio-substituted anthraquinone (Compound 3) (1)}

1-Butylpropionylthio-9,10-dioxo-anthraquinone (3)

$\mathrm{Cl}$ substitution on anthraquinone ring can give a nucleophilic substitution reaction and different nucleophilic groups can chemically bond to the ring. Compound $\mathbf{3}$ is synthesized from the reaction of 1 -chloro-9,10-dioxo-anthraquinone 1 (1 g, $4.12 \mathrm{mmol}$ ) with butyl-3mercaptopropionate $2(0.66 \mathrm{~g}, 4.06 \mathrm{mmol})$ in a mixture of ethylene glycol and aqueous $\mathrm{KOH}$ solution (1). Orange solid, mp: $153-154{ }^{\circ} \mathrm{C}$. Yield: $1.18 \mathrm{~g}(78 \%)$ 
Rf [(Petroliumether/Dichloromethane) (1:1)]: 0.51 .

IR $\left(\mathrm{cm}^{-1}\right): \mathrm{U}=3019,2959$ (C-Harom), 1573 $(\mathrm{C}=\mathrm{C}), 1676(\mathrm{C}=\mathrm{O})$. UV-vis $\left(\mathrm{CHCl}_{3}\right): \lambda_{\max }(\mathrm{log} \varepsilon)$ $=382(3.91) ; 254$ (5.03) $\mathrm{nm}$.

$1_{\mathrm{H}} \mathrm{NMR}\left(499.74 \mathrm{MHz} \mathrm{CDCl}_{3}\right): \delta=0.89(\mathrm{~s}, 3 \mathrm{H}$, $\left.\mathrm{CH}_{3}\right), 1.33-4.04\left(\mathrm{~m}, 6 \mathrm{H}, \mathrm{CH}_{2}\right), 2.59(\mathrm{~s}, 2 \mathrm{H}$, S- $\left.\mathrm{CH}_{2}-\mathrm{CH}_{2}\right), 3.17\left(\mathrm{~s}, 2 \mathrm{H}, \mathrm{S}-\mathrm{CH}_{2}-\mathrm{CH}_{2}\right) 7.37-8.28$ (m, 7H, Harom).

${ }^{13} \mathrm{C}$ NMR (125.66 $\left.\mathrm{MHz}, \mathrm{CDCl}_{3}\right): \delta=13.7$ $\left(\mathrm{CH}_{3}\right), 19.1\left(\mathrm{CH}_{2}\right), 28.7\left(\mathrm{~S}-\mathrm{CH}_{2}-\mathrm{CH}_{2}\right), 31.4$

$\left(\mathrm{CH}_{3} \mathrm{CH}_{2} \mathrm{CH}_{2}\right), \quad 31.5 \quad\left(\mathrm{~S}-\mathrm{CH}_{2}-\mathrm{CH}_{2}\right), \quad 64.7$ $\left(\mathrm{COOCH}_{2}\right), 126.75,129.96,131.10,132.05$, 132.58,

133.84, 134.25, 138.21, 139.94 (Carom and

CHarom), 182.21, $184.25 \quad(\mathrm{C}=0)$. MS

$[+\mathrm{ESI}]: \mathrm{m} / \mathrm{z} 369.65[\mathrm{M}+\mathrm{H}]^{+}, \mathrm{C}_{20} \mathrm{H}_{21} \mathrm{~N}_{3} \mathrm{O}_{2},(\mathrm{M}$, $368.45 \mathrm{~g} / \mathrm{mol})$. Schematic representation of ester-substituted thio-anthraquinone compound (Figure 1.).



Figure 1. Schematic representation of estersubstituted thio-anthraquinone compound.

\section{Biological characterization of ester substitued thio-anthraquinone compound}

a) Antibacterial activity of thio-anthraquinone (Compound 3)

For antibacterial effect detection of the thioanthraquinone compound, the agar dilution method according to clinical and laboratory standards institute (formerly CLSI) is performed quantitatively (40). The antimicrobial activities are assessed against Gram- positive (Staphylococcus epidermidis (ATCC 12228), Staphylococcus aureus (ATCC 29213), Bacillus subtilis (ATCC 6633), Enterococcus faecalis (ATCC 29212), and Gram- negative bacteria (Klebsiella pneumoniae (ATCC 4352), Pseudomonas aeruginosa (ATCC 27853), Salmonella enteritidis (KUEN 349), Escherichia coli (ATCC 25922). Mueller-Hinton Agar (Fluka 70191) is utilized for identification of the qualitative antibacterial effect and to provide the strains. In order to specify the quantitative antibacterial effect, Mueller- Hinton broth (Fluka 90922) $(\mathrm{CAMBH})$ with $\mathrm{MgCl}_{2} \cdot 2 \mathrm{H}_{2} \mathrm{O}\left(10 \mathrm{mg} \mathrm{Mg}^{2+} / \mathrm{L}\right)$ and $\mathrm{CaCl}_{2} \cdot 6 \mathrm{H}_{2} \mathrm{O}\left(20 \mathrm{mg} \mathrm{Ca}^{2+} / \mathrm{L}\right)$ are used as a medium. Furthermore, gentamicin sulfate (Sigma G1272) is utilized as the reference antibiotic standard. 10 serial dilutions of the thio-anthraquinone compound between 0,01 $\mathrm{mg} / \mathrm{mL}-5,4 \mathrm{mg} / \mathrm{mL}$ with $\mathrm{CAMBH}$ are prepared in sterile tubes. $1 \mathrm{ml}$ of each inoculum are poured to each petri dishes and $9 \mathrm{ml}$ of MullerHinton agar which is brought to $50{ }^{\circ} \mathrm{C}$ and is added onto inoculum. Subsequently, it is mixed with a circular dial until cooling to room temperature. Bacterial suspensions with $10^{7}$ $\mathrm{cfu} / \mathrm{ml}$ final concentration are prepared and added into the microplate wells. The sterilized replicator with 3-mm pins which deliver $2 \mu \mathrm{L}$ are placed into the microplate to soak the pins and transferred onto the agar plate. The agars are incubated at $37^{\circ} \mathrm{C}$ for 24 hours. The minimum inhibitory concentration, MIC, value is determined beyond the level no inhibition of growth of test organisms are observed.

b) Antifungal activity of thio-anthraquinone (Compound 3)

The antifungal effect of the thio-anthraquinone compound against yeast and fungi is examined with minimum inhibitor concentration using (MIC) broth macro dilution method according to CLSI (32). The antifungal activities are evaluated against yeasts (Candida albicans, Malassezia pachydermatis) and fungi (Microsporum canis and Trichophyton mentagrophytes.

Suspension equal to 0.5 McFarland turbidity in physiological salty water among 48-hour $C$. albicans and $M$. pachydermatis strains and 5 days $M$. canis and $T$. mentagrophytes strains in Sabouraud Dextrose Agar (SDA) (Sigma S3181) are prepared in order to get the inoculum. The MIC of the compound is determined by two-fold micro-dilution method in RPMI 1640 Medium (Sigma R8758) according to CLSI. Amphotericin B (Sigma 1032007) is used as the positive control. The lowest concentration that completely inhibits the reproduction and can be determined with the naked eye, i recorded as the MIC value.

\section{Preparation of electrospinning solutions}

Polycaprolactone, average molecular weight (Mw) $80,000 \mathrm{~g} / \mathrm{mol}$, is obtained from SigmaAldrich and used without further treatment or purification. PCL is dissolved in chloroform/dimethylformamide (DMF) solution with a constant $w / w 3: 2$ ratio. On the other hand, the synthesized ester-substituted thioanthraquinone compound is also added to the obtained solution and both of them are stirred sufficiently at range of $30-40{ }^{\circ} \mathrm{C}$. Different compositions are prepared as $6 \% \mathrm{PCL}, 6 \% \mathrm{PCL}-$ $1 \%$ Compound 3, 6\% PCL-5\% Compound 3 and $6 \%$ PCL-8\% Compound 3.

Properties of the electrospinning solution (viscosity, molecular weight of the polymer), 
should be determined before the jet. High molecular weight PCL is chosen purposefully in the present study, in order to produce nanofibers not nanoparticles. If lower molecular weight ones are used, low viscous solutions are obtained and hence the presence of beads are observed. Whereas, with very high molecular weight polymer, fibers wider than nano scale are produced which is not preferred. The viscosity of polymeric solution has been adjusted as well, to maintain nanofibers and optimize their fiber sizes, hence their morphology. Too high a viscosity results in drying of the droplet when coming out at the tip of the needle. PCL solution density is adjusted as $6 \% \mathrm{PCL}$ and so the viscosity. So as an optimum solution viscosity and $\mathrm{Mw}_{\mathrm{w}}$ is chosen for continuous smooth fibers without any agglomeration and beads.

\section{Production of Nanobiocomposite Mats via Electrospinning Method}

In order to get nanofiber structures but not nanoparticles solution parameters should be determined and process parameters should be adjusted. (a) The prepared electrospinning solution (b) Nanocomposite mat production via electrospinning method (Figure 2.).


Figure 2. (a) The electrospinning solution (b) Nanocomposite mat production via electrospinning method.
One of the most important parameters among the controllable variables during electrospinning is the applied voltage. Taylor cone is an indication of the critical voltage for electrospinning to occur. The critical voltage depends on the distance between the collector and the tip, surface tension of the solution, the tip radius and length of the pipette. Once the critical voltage is reached, the electrical force become sufficient to overcome the surface tension resulting in a taylor cone for electrospinning. Higher voltage yields to better electrospun fibers in nanoscale. Size of the fibers can also be easily varied by altering the distance between the tip and the collector. When the distance between the tip and collector are too small, the fibers are deposited on the collector even before the solvent evaporates. Schematic representation of the electrospinning method (Figure 3.).

To obtain homogenous fiber structures, process parameters have been set. The applied voltage is in the range of 15-31.8 kV while a Taylor cone is observed at a voltage of $12.3 \mathrm{kV}$. Humidity of the internal process area is recorded as $44.6 \pm 5 \%$. The flow rate of the digital syringe pump is $1 \mathrm{ml} / \mathrm{h}$ and the average distance between the tip of needle and collector is set to $12 \mathrm{~cm}$. Solution parameters of the obtained biocomposite electrospun mats are given in Table 1.

In the present study, solution parameters are also determined. Table 1 summarizes the solution parameters that are worked with. Increasing the crystalline content by incorporating Compound 3, mixture temperature or the mixing time to maintain a clearly dissolved solution increased $(42,43)$. This can be attributed to the rigid anthraquinone structure which increases the crystallinity $(37,44)$.

Table 1. Solution parameters of the obtained biocomposite electrospun mats.

\begin{tabular}{|c|c|c|c|c|}
\hline \multicolumn{2}{|c|}{ Polymer/ Compound 3Solvent } & \multirow{2}{*}{$\begin{array}{r}\begin{array}{l}\text { Solvent } \\
\text { ratio(w/v) }\end{array} \\
3: 2\end{array}$} & \multirow{2}{*}{$\begin{array}{r}\text { Mixture } \\
\text { Temp. }\left({ }^{\circ} \mathbf{C}\right) \\
30\end{array}$} & \multirow{2}{*}{$\begin{array}{l}\text { Mixing time } \\
\text { (min) } \\
45\end{array}$} \\
\hline PCL & $\begin{array}{l}\text { Chloroform/ } \\
\text { DMF }\end{array}$ & & & \\
\hline PCL-1\% Compound 3 & $\begin{array}{l}\text { Chloroform/ } \\
\text { DMF }\end{array}$ & $3: 2$ & 30 & 45 \\
\hline PCL-5\% Compound 3 & $\begin{array}{l}\text { Chloroform/ } \\
\text { DMF }\end{array}$ & $3: 2$ & 33 & 47 \\
\hline PCL-8\% Compound 3 & $\begin{array}{l}\text { Chloroform/ } \\
\text { DMF }\end{array}$ & $3: 2$ & 36 & 48 \\
\hline
\end{tabular}






Figure 3. Schematic representation of the electrospinning method.

\section{Characterization of the Nanobiocomposite Mats}

Morphological investigation of $\mathrm{PCL}$ and $\mathrm{PCL}$ composites having $1 \%, 5 \%, 8 \%$ Compound 3 by electrospinning method have been performed using FEI Quanta 450 FEG model scanning electron microscope (FEGSEM) under an applied voltage of $7.0 \mathrm{kV}$. Dimensional analysis and the topological investigation have also been conducted for the samples. Nanofibers' diameters are estimated using Image J software (National Institutes of Health, Bethesda, MD, USA) over 100 places in SEM images. Additionally, topologies of the samples are calculated similarly $(45,46)$.

Tensile tests of the electrospun nanofiber mats ( $\mathrm{PCL}$ and $\mathrm{PCL}$ composites having 1\%/5\%/ $8 \%$ content of Compound 3 ) are conducted according to ASTM E4 standards. Tensile strengths of the nanofiber mats are calculated with a rectangular specimen and a size of $1 \times 5$ $\mathrm{cm}$, under $500 \mathrm{~N}$ load by an Instron Brand test machine. The nanofiber thicknesses measured before the mechanical test and are in the range of 0.01-0.18 mm. Tests have been carried out at a constant jerk of $5 \mathrm{~mm} / \mathrm{min}$ at a jaw distance of $10 \mathrm{~cm}$ (32). Elongation values and UTS (ultimate tensile strength) points are measured by Instron 4411 tensile test machine with specific software (Bluehill 2, Elancourt, France). Each set of sample is tested 5 times and their averages are taken.

For antibacterial effect detection of the electrospun mats, the agar dilution method according to clinical and laboratory standards institute (formerly CLSI) is performed quantitatively $(3,47)$. The antimicrobial activities are assessed against Gram-positive (Staphylococcus aureus (ATCC 29213)), and
Gram-negative (Escherichia coli (ATCC 25922) bacteria and yeast (Candida albicans).

In-vitro tests for the electrospun mats have been conducted as follows;

Sample Preparation:

The nanocomposite mat films are cut to $10 \times 10$ $\mathrm{mm}$ and the films are washed 3 times in $70 \%$ ethanol. In the third wash, the samples are left in the alcohol for $30 \mathrm{~min}$. The samples are then washed 3 times with PBS for 5 minutes. One sample from each group is covered with culture media and kept in incubator at $37^{\circ} \mathrm{C}$ for 48 hours for degradation and contamination control.

\section{Cell culture:}

After control experiments, samples are cultured with immortalized human lung bronchial epithelial cell line (BEAS-2B) to detect any toxic effects of the molecule. $6 \times 10^{6}$ cells are seeded on three samples from each group with $200 \mu$ l culture media (RPMI 1640 with $10 \%$ Fetal Bovine Serum and 1\% Penisilin/Streptomisin). After 10 minutes, $1.8 \mathrm{ml}$ of culture media is added to each well of culture plates. Three wells without polymers are used as controls. The samples are then incubated with the cells for 72 hours and observed on an inverted microscope after 24,48 and 72 hours, they were observed on an inverted microscope. After 72 hours, the cells are microscopically examined for viability. The wells are collected, washed with PBS and fixed with $70 \%$ methanol for 20 minutes in a refrigerator. For the detection of dead cells, samples are stained and incubated with 100 $\mathrm{ng} / \mathrm{ml}$ propidium iodide (PI) solution for 10 minutes. The cells are evaluated and photographed under a Zeiss AxioScope Z1 LED fluorescent microscope (48-51). 


\section{RESULTS AND DISCUSSION}

Synthesis and characterization of estersubstituted thio-anthraquinone compound The synthesized of thio-anthraquinone compound has been obtained by the reaction of 1-chloro-9,10-dihydroxy-anthraquinone and butyl-3-mercaptopropionate in a mixture of ethylene glycol and aqueous solution of $\mathrm{KOH}$ (1). The obtained thio-anthraquinone compound is an orange solid and is stable. The resultant thio-anthraquinone compound has been synthesized for the first time in the literature and its applications as a biomaterial are discussed in the present study.

\section{Structural characterization results of ester-substituted thio-anthraquinone compound}

The characteristic $-\mathrm{C}=\mathrm{O}$ band of anthraquinone skeleton for Compound 3 is detected at 1671 $\mathrm{cm}^{-1}$, on the other hand, $3019 \mathrm{~cm}^{-1}$ and 1557 $\mathrm{cm}^{-1}$ can be attributed to the aromatic structure in the IR spectrum. In the ${ }^{13} \mathrm{C}$ NMR of compound 3 , carbon atom of the ester carbonyl gave a peak at $184.25 \mathrm{ppm}$ whereas, in ${ }^{1} \mathrm{H}$ NMR haracteristic sulfur-hydrogen peaks are detected at 2.59 and $3.17 \mathrm{ppm}$. Moreover, the molecular ion peak of $\mathrm{S}$ - substituted anthraquinone compound 3 is observed at $\mathrm{m} / \mathrm{z}$ $369.65[\mathrm{M}+\mathrm{H}]^{+}$.

Antimicrobial Test Results of estersubstituted thio-anthraquinone compound It is found that the thio-anthraquinone compound demonstrates effectiveness against S.aureus, S.epidermidis and $B$. subtilis $(0,27$ $\mathrm{mg} / \mathrm{mL}$ ). It is observed that the extract has no activity on Enterococcus faecalis, Escherichia coli, Klebsiella pneumoniae, Pseudomonas aeruginosa, and Salmonella enteritidis. Regarding the antibacterial activity, the results reveal that the compound displays significant inhibitory effects on the growth of the tested Gram positive bacteria similiar to that of a positive control (Gentamisin).

No antibacterial activity has been observed against all of the tested Gram negative bacteria. The result concerning the in vitro antibacterial activity of the thio-anthraquinone compound is presented in Table 2.

Table 2. The result concerning the in vitro antibacterial activity of the Thio-anthraquinone compound.

\begin{tabular}{cc}
\hline Bacteria & $\begin{array}{l}\text { Thio-anthraquinone } \\
\text { compound (3) }(\mathbf{m g} / \mathbf{m L})\end{array}$ \\
\hline S.aureus & 0.27 \\
\hline S.epidermidis & 0.27 \\
\hline B.subtilis & 0.27 \\
\hline K.pneumoniae & $(-)$ \\
\hline E.faecalis & $(-)$ \\
\hline E.coli & $(-)$ \\
\hline P.aeruginosa & $(-)$ \\
\hline
\end{tabular}

S.enteritidis

$(-)$; MIC value is not detected in the test concentrations

Table 3. The result concerning the in vitro antifungal activity of the thio-anthraquinone compound.

\begin{tabular}{ll}
\hline & $\begin{array}{l}\text { Thio-anthraquinone } \\
\text { compound } \\
\mathbf{3}(\mathbf{m g} / \mathbf{m L})\end{array}$ \\
\hline Yeasts & \\
C.albicans & 0,0675 \\
$\begin{array}{l}\text { M.pachydermatis } \\
\text { Fungi }\end{array}$ & 0,0843 \\
M.canis & 0.27 \\
T.mentagrophytes 0.27 \\
\hline
\end{tabular}

The effectiveness of the thio-anthraquinone compound is recorded effectiveness in different concentrations against yeasts and fungi. The compound showed a significant activity against C. albicans $(0.0675 \mathrm{mg} / \mathrm{mL})$ and $M$. pachydermatis $(0.0843 \mathrm{mg} / \mathrm{mL})$ and moderate inhibitory activity profile against $M$. canis and $T$. mentagrophytes $(0.27 \mathrm{mg} / \mathrm{mL})$. The results concerning the in vitro antifungal activity of the compound with MIC values are presented in Table 3. Regarding the antibacterial and antifungal activity, the results reveal that the thio-anthraquinone compound displays significant inhibitory effects on the growth of the tested Gram positive bacteria as S. aureus, $S$. epidermidis, $B$. subtilis and yeasts as $C$. albicans, M. pachydermatis. Additionally, antifungal activity against fungi is moderate and any antibacterial activity is not determined against all of the tested Gram negative bacteria.

\section{Production and Characterization of Nanobiocomposites}

$\mathrm{PCL}$ and ester-substituted thio-anthraquinone (Compound 3) solution was successfully converted into solid nanofibers through a single fluid-blending electrospinning. Calculated amounts of PCL and Compound 3 were used to obtain nanofiber mats. The nanofibers were produced with a single cone during electrospinning and exhibit homogenious morphology and without any agglomeration or discerned bead of Compound 3. For all nanfiber composites FEGSEM images with two different magnifications (3000x and 12000x) as well as their topology and fiber diameter histograms are illustrated in Figure 5. illustrated. 


\section{Structural Characterization Result}



Figure 4. FTIR Spectra of thio-anthraquinone (Compound 3 ) and PCL- $8 \%$ Compound 3 Nanocomposite.

FTIR Spectra of thio-anthraquinone (Compound 3) and PCL-8\% Compound 3 Nanocomposite are shown in Figure 4. For the nanocomposite, aliphatic $-\mathrm{CH}_{2}$ stretching can be observed in between 2945-2866 cm-1. The bands at 1164 $\mathrm{cm}^{-1}, 1239 \mathrm{~cm}^{-1}$ and $1294 \mathrm{~cm}^{-1}$ are due to the symmetric stretching of $\mathrm{C}-\mathrm{O}-\mathrm{C}$ groups in the polymer. The strong band at $1721 \mathrm{~cm}^{-1}$ belongs to the characteristic carbonyl $(\mathrm{C}=\mathrm{O})$ stretching for PCL (52) Moreover, aromatic bands at 3019 $\mathrm{cm}^{-1}$, aliphatic stretching bands between $2800-$ $2900 \mathrm{~cm}^{-1}$ and bands between $1200-1000 \mathrm{~cm}^{-1}$ comes from the synthesized thio-anthraquinone structure. The distinguishable bands for thioanthraquinone Compound 3 on the other hand, carbonyl $(\mathrm{C}=\mathrm{O})$ and aromatic $(\mathrm{C}=\mathrm{C})$ peaks, are observed at $1676 \mathrm{~cm}^{-1}$ and $1573 \mathrm{~cm}^{-1}$ respectively (53).

FEGSEM images of nanocomposites at two different magnifications (3000x and 12000x), their histograms and topological views are shown in Figure 5. PCL and ester-substituted thio-anthraquinone (Compound 3) solution is successfully converted into solid nanofibers through a single fluid-blending electrospinning. Calculated amounts of PCL (as indicated in materials and methods section) and Compound 3 were used to obtain nanofiber mats. The nanofibers were produced by a single cone electrospinning method and homogenious morphology, without any agglomeration or discerned bead of Compound 3, are obtained. For all nanofibers, FEGSEM images with two different magnifications (3000x and 12000x) as well as their topology and histogram of the fiber diameters were illustrated. In all the nanofiber mats, the size distribution is narrow and the histograms reveal that the size of the produced nanofibers are in the range of nanoscale. By incorporation of Compound 3, the solution conductivity is increased due to anthraquinone structure, hence thinner and finer fiber formation is achieved $(42,54)$. As a result, when FEGSEM images and histograms of the biocomposite mats are examined, a noticeable decreament in mean fiber diameters is observed. 


\section{Morphological Characterization and EDS Test Results}



A. FEGSEM images for PCL nano mats at two different magnifications (3000x and 12000x), histogram and topology of PCL nano mats.



B. FEGSEM images for PCL-1\% Compound 3 SEM nano mat at two different magnifications (3000x and $12000 \mathrm{x}$ ), histogram and topology of PCL-1\% Compound 3 nano mats



C. FEGSEM images for PCL-5\% Compound 3 SEM nano mat at two different magnifications 
(3000x and 12000x), histogram and topology of PCL-5\% Compound 3 nano mats



D. FEGSEM images for PCL-8\% Compound 3 SEM nano mat at two different magnifications (3000x and 12000x), histogram and topology of PCL-8\% Compound 3 nano mats

Figure 5. FEGSEM images of nanocomposites at two different magnifications (3000x and 12000x), their histograms and topological views.

Additionally, topology investigations reveal that porosity of the nanofiber mats are decreased owing to thinner fibers, thus enabling more uniform coatings and diameters distribution of the fibers. The porosity is important in cell growth and regeneration. For such a porous biodegradable biomaterial cells can find (42, 55-57).

\section{Antimicrobial Test Results}

Figure 6 shows the antimicrobial test results of the nanocomposites. as it is seen in Figure 7, the best antimicrobial activity can be seen for $\mathrm{PCL} / 5 \%$ Compound 3 samples. PCL/Compound
3 composite nanofibers have different antimicrobial effect against Gram (+) positive and Gram (-) negative bacteria and yeast. Considering the results, PCL/Compound 3 composite nanofibers are highly active against proliferation of the Candida albicans fungal colonies, moderately effective against Gram (+) positive Staphylococcus aureus strains and not very effective against Escherchia coli which is Gram (-) negative bacteria strain. 


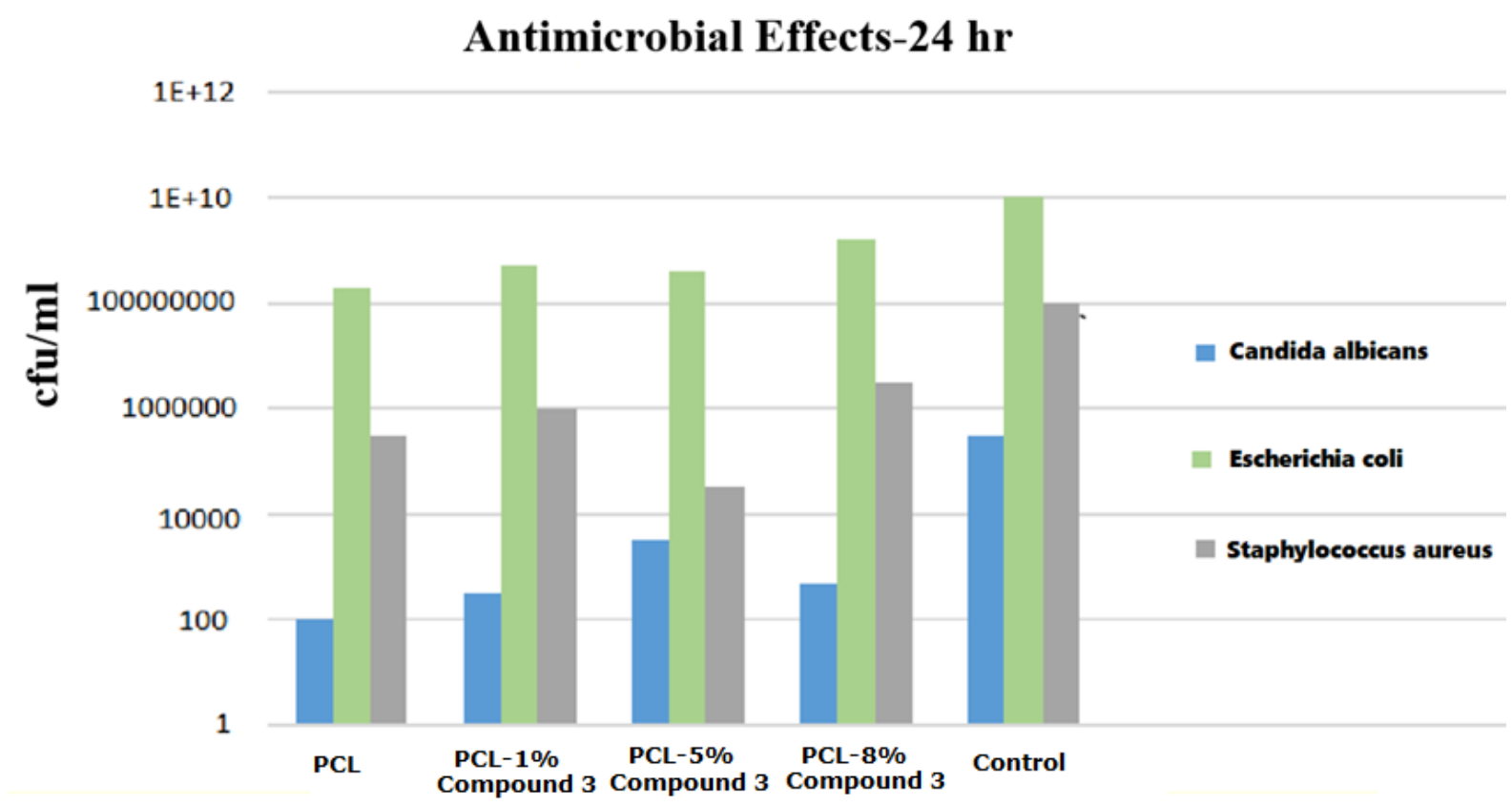

Figure 6. Antimicrobial results of the samples against three different kinds of microorganisms.

\begin{abstract}
In comparison to $\mathrm{PCL} / 5 \%$ Compound3 nanocomposite, $\quad \mathrm{PCL} / 8 \% \quad$ Compound3 nanocomposite is less effective against all microorganisms. This can be attributed to the agglomeration of Compound 3 and bead accumulation on nanofibers as can be supported by SEM images of $\mathrm{PCL} / 8 \%$ Compound 3 composite system. Irregularities such as bead formation or agglomeration on nanofiber mat ensure the adhesion of bacteria to the surface of the material. These homogeneities in the structure adversely affect the antimicrobial properties of the material $(42,58,59)$.
\end{abstract}

It was determined that there is no suitable environment for the adhesion and repletion of bacteria on flat surfaces. Such a flat surface hinders adhesion to the surface material $(60,61)$. For this purpose, to increase the antimicrobial activity of this active compound, nanofiber production are planned and conducted during this study (62-64). In comparison to PCL the electrospun nanomat of PCL presents a slightly enhanced antimicrobial activity $(65,66)$. As it can be seen from the FEGSEM images, nanobiocomposites are found to be homogeneous and thinner nanofibers are produced as stable anthraquinone as percentage increases. This result is due to the conductivity increase of the solution by incorporation of Compound 3 and enhanced antimicrobial effect of our novel thioanthraquinone compound. 


\section{In vitro Test Results}


Figure 7. Light microscope images of nanofiber mats.


Figure 8. Light microscope images of cell-cultured nanofiber mats.


PCL-5\%

Compound 3


Figure 9. \% Viability of nanofiber mats with fluorescent dyeing. 
Figure 7-9, summarize the in vitro tests of the nanobiocomposites. The examinations are conducted with light microscope revealing that for all nanofibers, cells protect their viability in high order. For the nanocomposite fibers, cell attachments are also observed in all groups. During the examination of nanofibers, local replacement of cells are observed due to the movement of nanofibers on cells. In the fluorescence microscopy studies, nanocomposite fibers are observed to emit low level visible light under UV illumination. Fluorescence microscopy studies, reveals that the percentage of cells stained with PI is over $94 \%$ and no significant difference is detected in comparison to the control.For all nanocomposite mats, live cells, attached to the surface and stained with DAPI, were reported. Cell viability was $95 \%$ or greater for all polymer composites and the control.

\section{Mechanical Tests}

Tensile test results of pure PCL mat and the nanobiocomposites are shown in Figure 10. Mechanical properties of the electrospun nanofiber mats (PCL and PCL composites having $1 \% / 5 \% / 8 \%$ content of Compound 3) are identified according to ASTM E4 standards $(33,67)$. Figure 11 summarizes the tensile test results of the biocomposites.

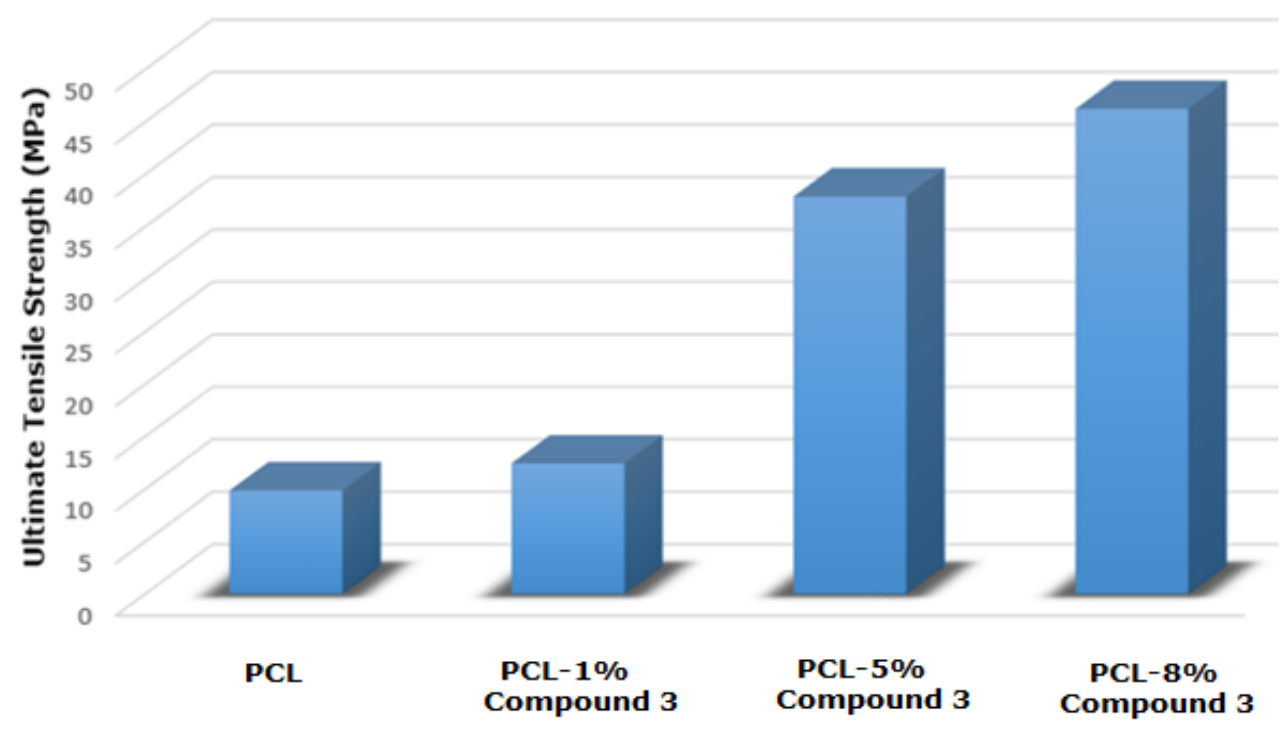

Figure 10. Tensile test results of pure PCL mat and the nanobiocomposites.

When the dimensions of the fibers are reduced to nano scale, owing to an increament in surface area/volume ratio, materials present better magnetic, optic, thermal, chemical, biological, and mechanical properties (68). Moreover, a rise in Compound 3 percent of the composite, enhances the mechanical strength of the material which can be attributed the rigid anthraquinone structure (69). In the light of morphological investigations, as can be understood from the FEGSEM images, the nanofibers are coated homogeniously with Compound 3 and no bead formation is observed which strenghtens the nanocomposites. Being consistent with morphological investigations, mechanical properties of the composites enhanced as Compound 3 content is increased. Several different PCL electrospun nanobiocomposites are present in the literature, however our mechanical results are one of the highest tensile strength among all (31, 70-72). This result is due to high surface area and homogeneity of the fibers, as well as a rigid anthraquinone structure incorporation to the composite mats.

\section{CONCLUSIONS}

A novel and simple synthesis method for biologically active ester-substituted anthraquinone derivative has been reported by our previous study. Having antimicrobial and bioactive properties, this stable thioanthraquinone derivative can find applications in drug delivery systems or in biomedical studies for regenerative and healing purposes.

Using this biologically active ester-substituted anthraquinone derivative nanocomposite mats have been produced. Nanocomposite morphologies have such a porous structure that can permit cell migration and growth. For the produced nanofiber mats cell viability percentages are found over $95 \%$ and enhanced mechanical properties are obtained by Compound 3 incoorporation. The results indicate that the purposefully produced electrospun nanofiber composites from this novel antimicrobial, biocompatible, ester-substituted anthraquinone compound hold potential for functional tissues, biomaterials such as stents and catheters or as wound healing materials. 


\section{ACKNOWLEDGMENTS}

The author would like to thank to Research Fund of the Istanbul Arel University (ArelBAP) for their financial support of the project. (Project Number: 2015.BAP.001). The author also would like to thank to Polymer Technologies and Composite Application and Research Center (ArelPOTKAM) for their help in material characterization. Also special thanks to Istinye University where biological tests were conducted.

\section{REFERENCES}

1. Ozkok F, Sahin Y M. Biyoaktif Antrakinon Analogları Ve Bunların Sentezine Yönelik Metot. TR. Patent No TR2016/19610.

2. Rath $G$ Ndonzao $M$, Hostettmann $K$. Antifungal anthraquinones from Morinda lucida. International journal of pharmacognosy. 1995; 33(2): 107-114.

3. Cowan M M. Plant products as antimicrobial agents. Clinical microbiology reviews. $1999 ; 12(4)$ : 564-582.

4. Nomura T, Fukai T. Phenolic constituents of licorice (Glycyrrhiza species). In: Fortschritte der Chemie organischer Naturstoffe/Progress in the Chemistry of Organic Natural Products. Springer Vienna, 1998; p 1-140.

5. Ali A M, Ismail N H, Mackeen M M, Yazan L S, Mohamed S M, Ho A S H, Lajis N H. Antiviral, cyototoxic and antimicrobial activities of anthraquinones isolated from the roots of Morinda elliptica. Pharmaceutical Biology. 2000; 38(4): 298-301.

6. Agarwal S K, Singh S S, Verma S, Kumar S. Antifungal activity of anthraquinone derivatives from Rheum emodi. Journal of ethnopharmacology. 2000; 72(1-2): 43-46.

7. Kupchan S M, Karim A. Tumor inhibitors. 114. Aloe emodin: antileukemic principle isolated from Rhamnus frangula L. Lloydia. 1976; 39(4): 223-224.

8. Velasquez W S, Lew D, Grogan TM, Spiridonidis C H, Balcerzak S P, Dakhil S R, Fisher R

I. Combination of fludarabine and mitoxantrone in untreated stages III and IV low-grade lymphoma: S9501. Journal of clinical oncology. 2003; 21(10): 1996-2003.

9. Thomas X, Archimbaud E. Mitoxantrone in the treatment of acute myelogenous leukemia: a review. Hematology and cell therapy. 1997; 39(4): 163-174.

10. Shenkenberg $T$, Von Hoff $D$ D.
Mitoxantrone: a new anticancer drug with significant clinical activity. Annals of internal medicine. 1986; 105(1): 67-81.

11. Neuhaus O, Kieseier B C, Hartung H P. Therapeutic role of mitoxantrone in multiple sclerosis. Pharmacology \& therapeutics. 2006; 109(1-2): 198-209.

12. Berger T. Current therapeutic recommendations in multiple sclerosis. Journal of the neurological sciences. 2009; 287: S37S45.

13. Li N, Ma $Y$, Yang C, Guo L, Yang $X$. Interaction of anticancer drug mitoxantrone with DNA analyzed by electrochemical and spectroscopic methods. Biophysical chemistry. 2005; 116 (3): 199-205.

14. Lown J W, Morgan A R, Yen S F, Wang $Y$ $\mathrm{H}$, Wilson W D. Characteristics of the binding of the anticancer agents mitoxantrone and ametantrone and related structures to deoxyribonucleic acids. Biochemistry. 1985; 24(15): 4028-4035.

15. Agarwal S, Jangir D $\mathrm{P}$, Mehrotra $\mathrm{R}$. Spectroscopic studies of the effects of anticancer drug mitoxantrone interaction with calf-thymus DNA. Journal of Photochemistry and Photobiology B: Biology. 2013; 120: 177182.

16. Pommier $\mathrm{Y}$, Leo $\mathrm{E}$, Zhang $\mathrm{H}$, Marchand $\mathrm{C}$. DNA topoisomerases and their poisoning by anticancer and antibacterial drugs. Chemistry \& biology. 2010; 17(5): 421-433.

17. Hande K R. Topoisomerase II inhibitors. Update on Cancer Therapeutics. 2008; 3(1): 13-26.

18. Montoya, S. N., Comini, L. R., \& Cabrera, J. L. (2011). Antimicrobial activity of natural photosensitizing anthraquinones.

19. Ali, A. M., Ismail, N. H., Mackeen, M. M., Yazan, L. S., Mohamed, S. M., Ho, A. S. H., \& Lajis, N. H. (2000). Antiviral, cyototoxic and antimicrobial activities of anthraquinones isolated from the roots of Morinda elliptica. Pharmaceutical Biology, 38(4), 298301

20. Gouda, M. A., Berghot, M. A., Shoeib, A. I., \& Khalil, A. M. (2010). Synthesis and antimicrobial of new anthraquinone derivatives incorporating pyrazole moiety. European journal of medicinal chemistry, 45(5), 18431848.

21. Nor, S. M. M., Sukari, M. A. H. M., Azziz, S. S. S. A., Fah, W. C., Alimon, H., \& Juhan, S. F. (2013). Synthesis of new cytotoxic aminoanthraquinone derivatives via 
nucleophilic substitution

reactions. Molecules, 18(7), 8046-8062.

22. Routier, S., Cotelle, N., Catteau, J. P., Bernier, J. L., Waring, M. J., Riou, J. F., \& Bailly, C. (1996). Salen-anthraquinone conjugates. Synthesis, DNA-binding and cleaving properties, effects on topoisomerases and cytotoxicity. Bioorganic \& medicinal chemistry, 4(8), 1185-1196:

23. Ishmael, D. R., \& Adelsteinsson, $\mathrm{O}$. (2014). 1, 4, 5, 8-Tetrakis-[(2-N, Ndimethylaminoethyl) amino] anthraquinone as a potential anticancer agent: its synthesis, characterization and anticancer properties.

24. Teng, C. H., Won, S. J., \& Lin, C. N. (2005). Design, synthesis and cytotoxic effect of hydroxy-and 3-alkylaminopropoxy-9, 10anthraquinone derivatives. Bioorganic \& medicinal chemistry, 13(10), 3439-3445.

25. Gouda, M. A., Berghot, M. A., Shoeib, A. I., \& Khalil, A. M. (2010). Synthesis and antimicrobial of certain new thiazolidinone, thiazoline, and thiophene

derivatives. Phosphorus, Sulfur, and Silicon and the Related Elements, 185(7), 1455-1462.

26. Ibis, C., Tuyun, A. F., Bahar, H., Ayla, S. S., Stasevych, M. V., Musyanovych, R. Y., ... \& Novikov, V. (2013). Synthesis of novel 1 , 4-naphthoquinone derivatives: antibacterial and antifungal agents. Medicinal Chemistry Research, 22(6), 2879-2888.

27. Huang, H. S. (2005). U.S. Patent Application No. 10/615,695.

28. Huang, H. S., Chiou, J. F., Chiu, H. F., Hwang, J. M., Lin, P. Y., Tao, C. W., ... \& Jeng, W. R. (2002). Synthesis of symmetrical 1, 5bis-thio-substituted anthraquinones for cytotoxicity in cultured tumor cells and lipid peroxidation. Chemical and pharmaceutical bulletin, 50(11), 1491-1494.

29. Lord W M, Peters A T. Reactions in NNdimethylformamide. Part II. Halogen replacement in the anthraquinone series. Journal of the Chemical Society C: Organic. $1968 ; 783-785$.

30. Ruediger E H, Kaldas M L, Gandhi S S, Fedryna C, Gibson M S. Reactions of 1, 5dichloroanthraquinone with nucleophiles. The Journal of Organic Chemistry. 1980; 45(10): 1974- 1978.

31. Zhang $\mathrm{Y}$, Ouyang $\mathrm{H}$, Lim C T, Ramakrishna $S$, Huang $Z$ M. Electrospinning of gelatin fibers and gelatin/PCL composite fibrous scaffolds. Journal of Biomedical Materials Research Part B: Applied Biomaterials. 2005; 72(1): 156-165.
32. Kehoe $S$, Zhang, $X$ F, Boyd D. FDA approved guidance conduits and wraps for peripheral nerve injury: a review of materials and efficacy. Injury. 2012; 43(5): 553-572.

33. Polat E. Polikaprolaktonun Elektrostatik Eğirmesi ve Rgd Yüzey Modifikasyonu ile Periferik Sinir İyileşme Kanalları Üretim ve Karakterizasyonu. Fen Bilimleri Enstitüsü, Yüksek Lisans Tezi, 2013 Ankara.

34. Sahin Y M, Su S, Ozbek B, Yucel S, Pinar O, Kazan D, Gunduz $O$. Production and characterization of electrospun fish sarcoplasmic protein based nanofibers. Journal of Food Engineering. 2018; 222: 54-62.

35. Aliakbarshirazi S, Talebian A. Electrospun gelatin nanofibrous scaffolds for cartilage tissue engineering. Materials Today: Proceedings. 2017; 4(7): 7059-7064.

36. Erdem R, Sancak E. Elektroçekim yöntemiyle elde edilen poliamid 6/kitosan bazlı nanoliflerin morfolojik özelliklerinin incelenmesi. İstanbul Ticaret Üniversitesi Fen Bilimleri Dergisi. 2013; 12.24: 53.

37. Burger C, Hsiao B S, Chu B. Nanofibrous materials and their applications. Annual Review of Materials Research. 2006; 36: 333-368.

38. Buluş E. Doğal izole edilmiş biyoseramiklerden elektrospinning yöntemi ile polimerik biyokompozit malzeme eldesi, Fırat Üniversitesi, Fen Bilimleri Enstitüsü, Yüksek lisans tezi, 2017 Elazığ.

39. Sill T J, Von Recum H A. Electrospinning: applications in drug delivery and tissue engineering. Biomaterials. 2008; 29(13): 19892006.

40. Jones R N, Sader H S, Mendes R E, Flamm $\mathrm{R} \mathrm{K}$. Update on antimicrobial susceptibility trends among Streptococcus pneumoniae in the United States: report of ceftaroline activity from the SENTRY Antimicrobial Surveillance Program (1998-2011). Diagnostic microbiology and infectious disease. 2013; 75(1): 107-109.

41. Cuenca-Estrella M, Gomez-Lopez A, Alastruey-Izquierdo A, Bernal-Martinez L, Cuesta I, Buitrago M J, Rodriguez-Tudela J L. Comparison of the Vitek 2 antifungal susceptibility system with the Clinical and Laboratory Standards Institute (CLSI) and European Committee on Antimicrobial Susceptibility Testing (EUCAST) broth microdilution reference methods and with the Sensititre YeastOne and Etest techniques for in vitro detection of antifungal resistance in yeast isolates. Journal of clinical microbiology. 2010; 48(5): 1782-1786.

42. Zhu G, Li T. Properties of polyurethane- 
polystyrene graft copolymer membranes used for separating water-ethanol mixtures. European polymer journal. 2005; 41(5): 10901096.

43. Jeevitha D, Amarnath K. Chitosan/PLA nanoparticles as a novel carrier for the delivery of anthraquinone: Synthesis, characterization and in vitro cytotoxicity evaluation. Colloids and Surfaces B: Biointerfaces. 2013; 101: 126-134.

44. Meng J G, Feng X T, Bai J. Aloe Fiber and Pure Yarn Research on Performance. In: Advanced Materials Research. Trans Tech Publications. 2012; p. 284-288.

45. Oflaz K. Manyetik nanofiber membranlar, Selçuk Üniversitesi, Fen Bilimleri Enstitüsü, Doktora Tezi, 2016 Konya.

46. Liu X, Shao W, Luo M, Bian J, Yu D G. Electrospun Blank Nanocoating for Improved Sustained Release Profiles from Medicated Gliadin Nanofibers. Nanomaterials. 2018; 8(4): 184.

47. Pfaller M A, Farrell D J, Sader H S, Jones R N. AWARE Ceftaroline Surveillance Program (2008- 2010): trends in resistance patterns among Streptococcus pneumoniae, Haemophilus influenzae, and Moraxella catarrhalis in the United States. Clinical infectious diseases. 2012; 55.suppl_3: S187S193.

48. Imam $\mathrm{S} H$, Cinelli $\mathrm{P}$, Gordon $\mathrm{S} \mathrm{H}$, Chiellini E. Characterization of biodegradable composite films prepared from blends of poly (vinyl alcohol), cornstarch, and lignocellulosic fiber. Journal of Polymers and the Environment. 2005; 13(1): 47-55.

49. Pan H, Fan D, Cao W, Zhu C, Duan Z, Fu R, $\mathrm{Ma} X$. Preparation and Characterization of Breathable Hemostatic Hydrogel Dressings and Determination of Their Effects on Full-Thickness Defects. Polymers. 2017; 9(12): 727.

50. Karp J M, Shoichet M S, Davies J E. Bone formation on two-dimensional poly (DL-lactideco- glycolide)(PLGA) films and threedimensional PLGA tissue engineering scaffolds in vitro. Journal of biomedical materials research. Part A 2003; 64(2): 388-396.

51. Çaydamlı Y. Elektrospinning yöntemi ile biyopolimer esaslı nanoyapıların hazırlanması ve karakterizasyonu, Dokuz Eylül Üniversitesi, Fen Bilimleri Enstitüsü, Doktora Tezi, 2012 İzmir.

52. Davila J L, Freitas $M S$, Inforçatti $N P$, Silveira Z C, Silva J V L, d'Ávila M A. Fabrication of $P C L / \beta$ - TCP scaffolds by 3D mini-screw extrusion printing. Journal of Applied Polymer Science. 2016; 133(15).
53. Shakhes J, Zeinaly F, Marandi M A, Saghafi $T$. The effects of processing variables on the soda and soda-aq pulping of kenaf bast fiber. BioResources. 2011; 6(4): 4626-4639.

54. Kuhn $\mathrm{H} \mathrm{H}$. Anthraquinone-2-sulfonic acid doped conductive textiles. U.S. Patent No 5,108,829, 1992.

55. Üstündağ G C. Electrospinning Yöntemi ile Biyomedikal Kullanıma Yönelik Nanolif Yüzey Üretimi ve Uygulaması. Fen Bilimleri Enstitüsü, Yüksek Lisans Tezi, 2009 Bursa.

56. Zeytuncu B. Elektrospinning Tekniği Ve Uv Işımasının Eşzamanlı olarak Uygulanması İle nanofiber Membranların Hazırlanması Ve Kıymetli Metallerin Adsorpsiyonunda Uygulanması, İstanbul Teknik Üniversitesi, Fen Bilimleri Enstitüsü, Doktora Tezi, 2014 İstanbul.

57. Suzuki M. Antibacterial composite nonwoven fabric. U.S. Patent No 5,652,049, 1997.

58. Anitha S, Brabu B, Thiruvadigal D J, Gopalakrishnan C, Natarajan T S. Optical, bactericidal and water repellent properties of electrospun nano-composite membranes of cellulose acetate and $\mathrm{ZnO}$. Carbohydrate Polymers. 2012; 87(2): 1065-1072.

59. An $\mathrm{YH}$, Friedman R J. Concise review of mechanisms of bacterial adhesion to biomaterial surfaces. Journal of Biomedical Materials Research Part A. 1998; 43(3): 338348.

60. Nilay C A N, Ersoy M S. Nanofiber Structured Polymeric Tissue Scaffolds. 2014; (Volume: 21), 2014, 95.

61. Erem A D. Nanokompozit Yapılı Tekstillerin Geliştirilmesi Ve Antimikrobiyal Özellik Kazandırılması, İstanbul Teknik Üniversitesi, Fen Bilimleri Enstitüsü, Doktora Tezi, 2012 İstanbul.

62. Schiffman J D, Schauer C L. Cross-linking chitosan nanofibers. Biomacromolecules. 2007; 8(2): 594-601.

63. Kayaci F, Um O. C, Tekinay T, Uyar T. Antibacterial electrospun poly (lactic acid)(PLA) nanofibrous webs incorporating triclosan/cyclodextrin inclusion complexes. Journal of agricultural and food chemistry. 2013; 61(16): 3901-3908.

64. Augustine $R$, Malik $H$ N, Singhal $D K$, Mukherjee A, Malakar D, Kalarikkal N, Thomas S. Electrospun polycaprolactone/ZnO nanocomposite membranes as biomaterials with antibacterial and cell adhesion properties. Journal of Polymer Research. 2014; 21(3): 347. 
65. Lowery J L, Datta N, Rutledge G C. Effect of fiber diameter, pore size and seeding method on growth of human dermal fibroblasts in electrospun poly ( $\varepsilon$-caprolactone) fibrous mats. Biomaterials. 2010; 31(3): 491-504.

66. Cengiz Çallığlu F. The Effect of Glyoxal Cross-Linker and $\mathrm{Nacl}$ Salt Addition on The Roller Electrospinning of Poly (Vinyl Alcohol) Nanofibers. Journal of Textile \& Apparel/Tekstil ve Konfeksiyon. 2014; 24(1).

67. Kumru A. Elektroüretimle Nanolif Eldesine Etki Eden Faktörlerin Ve Jelatin-pektin İçeren Nanoliflerin Model Gıdaların Reolojik Özelliklerine Etkilerinin İncelenmesi, İstanbul Teknik Üniversitesi, Fen Bilimleri Enstitüsü, Doktora Tezi, 2014 İstanbul.

68. Erdem R, Sancak E. İkili Besleme Ünitesi Sistemi ile Elektroçekimi Gerçekleştirilen PVA/Aloe barbadensis ve PEO/Kitosan Bazlı Nanolifli Yapıların Morfolojik ve Mekanik
Özelliklerinin İncelenmesi. Afyon Kocatepe Üniversitesi Fen Ve Mühendislik Bilimleri Dergisi. 2015; 14(1): 1-6.

69. Gaumer J, Prasad A, Lee D, Lannutti J. Structure-function relationships and source-toground distance in electrospun polycaprolactone. Acta Biomaterialia. 2009; 5(5): 1552-1561.

70. McClure $M$ J, Sell $S A$, Simpson D G, Walpoth B H, Bowlin G L. A three-layered electrospun matrix to mimic native arterial architecture using polycaprolactone, elastin, and collagen: a preliminary study. Acta biomaterialia. 2010; 6(7): 2422-2433.

71. Ebersole G C, Buettmann E G, MacEwan M $R$, Tang $M E$, Frisella $M M$, Matthews $B$, Deeken C

R. Development of novel electrospun absorbable polycaprolactone (PCL) scaffolds for hernia repair applications. Surgical endoscopy. 2012; 26(10): 2717-2728.

72. Lee S J, Oh S H, Liu J, Soker S, Atala A, Yoo J J. The use of thermal treatments to enhance the mechanical properties of electrospun poly ( $\varepsilon$-caprolactone) scaffolds. Biomaterials. 2008; 29: 1422-1430. 